prednisolone followed by a reducing course of oral prednisolone. She improved clinically and her erythrocyte sedimentation rate settled to $19 \mathrm{~mm}$ in the first hour after 10 days. The tracheostomy tube was removed after 12 days and good movement was seen in both vocal cords. Her recovery was further complicated by an extensive left deep venous thrombosis requiring anticoagulation.

Antinuclear factor titres rose to $>1 / 10240$ for both IgG and IgM. No anti-DNA binding was detected. C3 and $\mathrm{C} 4$ concentrations were normal. No lupus anticoagulant was detected. There was no evidence of renal impairment, though 24 hour urinary protein excretion was $0.56 \mathrm{~g}$ (normal $<0.150 \mathrm{~g}$ ).

Nine months after discharge she was well, her blood pressure being controlled with verapamil $120 \mathrm{mg}$ twice daily. Antinuclear factor titres had fallen to 1/1280 and all other values had returned to normal.

\section{Comment}

Our belief that the cause of our patient's bilateral 10th nerve palsies was hydralazine induced systemic lupus erythematosus was based on the clinical presentation, antibody state, and subsequent clinical and serological responses to hydralazine withdrawal and steroids.

Hydralazine induced systemic lupus erythematosus usually occurs after six months to two years of exposure to the drug. The disease is dose related and is uncommon at the dosage that our patient was receiving. ${ }^{2}$ Renal disease is unusual and to our know- ledge nervous system disease has been limited to isolated cases of peripheral neuritis, retrobulbar neuritis, loss of taste, and paraesthesias. ${ }^{3+}$ Antinuclear factor titres are high, usually with absent anti-doublestranded DNA antibodies and normal concentrations of complement, ${ }^{2}$ as in our patient. Remission occurs on withdrawal of the drug. Aspirin or other nonsteroidal drugs may be used for musculoskeletal symptoms but more serious manifestations warrant short term treatment with steroids. ${ }^{24}$ Full recovery is usual, as in our patient, though in her case this was not before serious and rapid complications had developed.

Since reporting this case we have seen a further patient who developed a 10th nerve palsy while receiving hydralazine $50 \mathrm{mg}$ twice daily for two years for hypertension complicating polycystic kidney disease; there was clinical and serological support for the diagnosis of hydralazine related systemic lupus erythematosus. In his case resolution of the palsy did not occur despite withdrawal of hydralazine and he subsequently died from ischaemic heart disease (confirmed at necropsy).

1 Cameron HA, Ramsay LE. The lupus syndrome induced by hydralazine: common complication with low dose treatment. Br Med f 1984;289:410-2. 2 Stratton MA. Drug-induced systemic lupus erythematosus. Clin Phar 1985;4:657-63.

3 Kirkendall WM, Page EB. Polyneuritis occurring during hydralazine therapy: report of two cases and discussion of adverse reactions to hydralazine. $\mathcal{F} A M$ $1958 ; 167: 427-32$

4 Alarcón-Segovia D, Wakim KG, Worthington JW, Ward LE. Clinical and experimental studies on the hydralazine syndrome and its relationship to svstemic lupus erythematosus. Medicine (Baltimore) 1967;46:1-33.

(Accepted 21 April 1988)

\section{Reduction of size of thyroid with radioactive iodine in multinodular non-toxic goitre}

\section{Laszlo Hegedüs, Bo Mølholm Hansen, Niels Knudsen, Jens Mølholm Hansen}

\section{Departments of Internal Medicine and \\ Endocrinology and \\ Ultrasound, Herlev \\ Hospital, DK-2730 Herlev, \\ Denmark \\ Laszlo Hegedüs, MD, senior \\ registrar \\ Bo Mølholm Hansen \\ medical student \\ Niels Knudsen, medical \\ student \\ Jens Mølholm Hansen, MD, \\ consultant physician}

Correspondence to:

Dr Laszlo Hegedüs,

Department of Internal

Medicine and

Endocrinology F, Herlev

Hospital, DK-2730 Herlev,

Denmark.
Treatment of hyperthyroidism with radioactive iodine (iodine-131) is well accepted and can achieve a substantial decrease in the size of the thyroid. ${ }^{1}$ Precise data on the effect of such treatment on the size of the thyroid in non-toxic goitre are lacking, and its potential role in this condition remains to be established. This study aimed at investigating the effects of treatment with iodine-131 on thyroid function and ultrasonically determined thyroid volume ${ }^{2}$ in patients with non-toxic goitre.

\section{Patients, methods, and results}

We studied 25 patients ( 24 women, one man; median age 56 (range 41-79)) who were followed up for a minimum of 12 months after treatment of non-toxic goitre with iodine-131. All patients had a multinodular goitre on technetium-99m thyroid scanning, and six had had a thyroidectomy. In all cases this treatment was chosen owing to a high operative risk, previous thyroidectomy, or refusal to be operated on. Informed consent was obtained from all patients. Serum thyroxine, triiodothyronine, and thyrotrophin concentrations, triiodothyronine resin uptake, and the size of the thyroid on ultrasonography were determined before treatment as well as one, two, three, six, and 12 months after treatment. ${ }^{2}$ Iodine-131 was given at a dose of $3 \cdot 7$ $\mathrm{MBq} / \mathrm{g}$ total thyroid mass corrected to a $100 \%$ uptake of iodine-131 in 24 hours. The median dose was 555 (range 244-1021) MBq.
Twenty of 23 patients who received one dose remained euthyroid during the 12 month follow up. Mean thyroid volume (normal range $9-28 \mathrm{ml}$ ) decreased gradually from 73.2 (SEM 6.4) $\mathrm{ml}$ to 43.2 $(5 \cdot 1) \mathrm{ml}$ at 12 months (figure; $\mathrm{p}<0.001$, Wilcoxon's test for paired data). Two patients developed permanent hypothyroidism two and three months after treatment, and one had transient hyperthyroidism lasting 10 months. In this last patient thyroid volume gradually decreased from 49 to $24 \mathrm{ml}$. Two patients were given two doses of iodine-131 to reduce the size of the thyroid; their thyroid volume decreased from 75 to $40 \mathrm{ml}$ and from 76 to $35 \mathrm{ml}$, and both remained euthyroid.

\section{Comment}

Suppressive treatment of diffuse non-toxic goitre with thyroxine or triiodothyronine reduces the thyroid

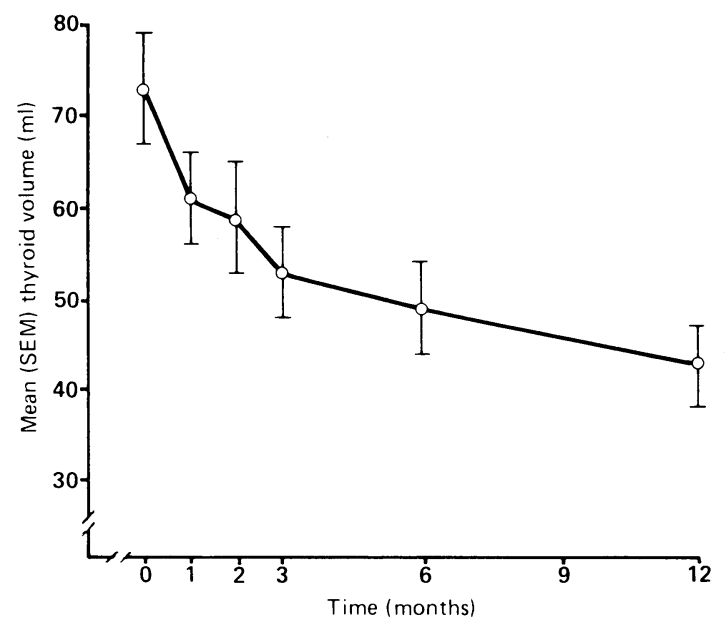

Mean (SEM) thyroid volume after treatment with iodine-131 in 20 patients with multinodular non-toxic goitre remaining euthyroid during follow up 
volume by some $20-30 \%,{ }^{3}$ but such an effect can probably not be achieved in multinodular glands. ${ }^{+}$This study shows a substantial reduction in the size of the thyroid in all patients treated with iodine-131; two patients, however, required an additional dose to achieve this. Although such an effect has been suggested by measurements of the circumference of the neck, ${ }^{5}$ data are not available for an objective technique of determining the size of the thyroid. An initial increase in thyroid volume was not seen in any of our patients; therefore this treatment could also be considered for patients with intrathoracic goitres. Hypothyroidism occurred in two of the 25 patients. A larger study and a longer follow up are required to evaluate the occurrence of hypothyroidism and to establish the optimal dose of iodine-131 and the maximum achievable reduction in size of the thyroid.
Treatment of non-toxic multinodular goitre with iodine-131 seems an attractive alternative to operation in patients with a high operative risk or after thyroidectomy or those who refuse operation.

1 Hegedüs L, Hansen JM. Radioactive iodine for thyrotoxicosis. Lancet 1986;ii: $339-40,876$

2 Hegedüs L, Perrild H, Poulsen LR, et al. The determination of thyroid volume by ultrasound and its relationship to body weight, age, and sex in normal by ultrasound and its relationship to body weight.

3 Perrild $\mathrm{H}$, Hansen JM, Hegedüs L, et al. Triiodothyronine and thyroxine treatment of diffuse non-toxic goitre evaluated by ultrasonic scanning. Acta
tring treatment of diffuse non-toxic goitre

4 Gharib H, James EM, Charboneau JW, et al. Suppressive therapy with levothyroxine for solitary thyroid nodules. A double-blind controlled clinical study. N Engl F Med 1987;317:70-5.

Frey KW. Früh und Spätergebnisse der ${ }^{131}$ I-Therapie der blanden Struma im Kropfendemiegebiet Südbayerns. Fortschritte Röntgenstralen 1979;130:172-4.

(Accepted 15 April 1988)

\title{
Review of postperinatal mortality in a health district with a garrison town
}

\author{
Mala Rao, Elizabeth Hoinville
}

North East Essex Health

Authority, District

Headquarters, Colchester CO4 5JR

Mala Rao, MFCM, specialist in community medicine

Department of Community Health, London School of Hygiene and Tropical

Medicine, London

Elizabeth Hoinville, MSC, statistician

Correspondence to: Dr Rao.
North East Essex health district is an area of relative affluence. Nevertheless, during the past decade its postperinatal mortality rate (deaths of babies between 1 week and 1 year of age/1000 live births) has exceeded the rate for England and Wales several times. Though the excess has not been statistically significant, a review of postperinatal deaths was carried out in response to concern among health care staff.

\section{Present study and results}

We examined the causes of and factors associated with deaths of babies between 1 week and 1 year of age during 1978 to 1983. All infants born to mothers usually resident in the district were included in the study. Of the 116 postperinatal deaths which occurred

Classification of postperinatal deaths and sudden infant death syndrome

\begin{tabular}{|c|c|c|c|c|c|}
\hline \multirow[b]{2}{*}{ Category of employment } & \multicolumn{2}{|c|}{ All postperinatal deaths } & \multicolumn{2}{|c|}{$\begin{array}{l}\text { Sudden infant death } \\
\text { syndrome deaths }\end{array}$} & \multirow[b]{2}{*}{$\begin{array}{l}\text { Total No o } \\
\text { live births }\end{array}$} \\
\hline & Total & $\begin{array}{l}\text { Death rate } / 1000 \\
\text { live births (SE) }\end{array}$ & Total & $\begin{array}{l}\text { Death rate } / 1000 \\
\text { live births (SE) }\end{array}$ & \\
\hline Army & 14 & $10 \cdot 2(2 \cdot 7)$ & 8 & $5 \cdot 8(2 \cdot 1)$ & 1372 \\
\hline $\begin{array}{l}\text { Social classes I, II, IIIN, IIIM, IV, V, } \\
\text { unemployed, students } \\
\text { Not known }\end{array}$ & $\begin{array}{r}90\} \\
4\}\end{array}$ & $5 \cdot 1(0 \cdot 5)$ & $\begin{array}{r}37 \mid \\
1\}\end{array}$ & $2 \cdot 1(0 \cdot 3)$ & 18325 \\
\hline Total & 108 & $5 \cdot 5(0.5)$ & 46 & $2 \cdot 3(0 \cdot 3)$ & 19697 \\
\hline
\end{tabular}

during the six years, eight were rejected because of lack of information. The remaining 108 deaths were examined and the most nctable finding was the contribution of army families to all postperinatal deaths and to deaths due to the sudden infant death syndrome.

In all, 14 deaths occurred in families in which the father was a soldier, so that the postperinatal death rate for army babies was $10 \cdot 2 / 1000$ live births compared with $5 \cdot 1 / 1000$ live births for all the other babies in the study $\left(\chi^{2}\right.$ test with Yates's correction $5 \cdot 14 ; p=0 \cdot 02$; $\mathrm{df}=1)($ table $)$.

A total of 46 babies were victims of the sudden infant death syndrome, of whom eight were army babies. The rate of the sudden infant death syndrome among army babies $(5 \cdot 8 / 1000$ live births) was therefore about three times the rate for all other babies $(2 \cdot 1 / 1000$ live births $)$ $\left(\chi^{2}\right.$ test with Yates's correction $6 \cdot 2 ; \mathrm{p}=0 \cdot 01 ; \mathrm{df}=1$ ).

The death rate from all other causes was $4 \cdot 4 / 1000$ live births for army babies and 3:1/1000 live births for all other babies ( $\chi^{2}$ test with Yates's correction 0.35 ; NS). The postperinatal death rate for army babies, which was twice the rate for other babies (relative risk $=2$; standard normal deviate $=2 \cdot 43 ; \mathrm{p}=0.02 ; 95 \%$ confidence interval $1 \cdot 14$ to $3 \cdot 50$ ), was therefore due mainly to the sudden infant death syndrome.

The epidemiological characteristics of all the deaths in the review mainly confirmed the patterns described in other studies, ${ }^{12}$ with some exceptions. Army mothers tended to be younger than other mothers (mean age $21 v 26$ years; NS), more of them smoked $(8(57 \cdot 1 \%) v 40(42 \cdot 6 \%)$; NS), and fewer intended to breast feed their babies compared with other mothers $(5(35 \cdot 7 \%) v 50(53 \cdot 2 \%)$; NS). Significantly more army families had a history of marital stress or violence, or both $(6(42.9 \%) v 14(14.9 \%) ; \mathrm{p}=0.05)$. The obvious constraint of a retrospective study based on examining written records is that data are almost certainly incomplete. Nevertheless, these differences were found.

\section{Comment}

The higher death rates in army babies compared with all other babies in the district is of concern to us for two reasons. A search of published work failed to identify any previous study examining infant mortality in other garrison towns for comparison with our results. Secondly, the health service input to the garrison, which contributes about 200 births a year, consists of two designated health visitors. We do not know what additional support might help reduce mortality in the army. We speculate that the young age of the mothers, their isolation in the garrison, and the lack of family support - given that Colchester is often not the home town of the soldiers or their wivesprobably all contribute to the higher mortality of these babies.

There were too few cases in this review to provide any concrete explanations for the differences in mortality. A case-control study of deaths since 1984 is being considered to shed light on the prospects for prevention.

1 Knowelden J, Keeling J, Nicholl JP. A multicentre study of post neonatal mortality. Medical Care Research Unit, University of Sheffield. London: HMSO, 1985 .

2 Peterson DR. Evolution of the epidemiology of sudden infant death syndrome. Epidemiol Rev 1980;2:97-112.

(Accepted 28 April 1988 